\title{
Classroom Teaching Expansion of Computer Fundamentals Course
}

\author{
SHANG Junping, LIU Hebing
}

Department of Computer Science \& Technology Henan Agricultural University Zhengzhou, China

\begin{abstract}
This paper mainly studies classroom teaching expansion of Computer Fundamentals Course. The classroom teaching of Computer Fundamentals Course can be expanded in the perspectives of time and space by using various resources such as library, Internet, science and technology market for non-computer major students. As shown in the practice results the students have really benefited a lot from these efforts.
\end{abstract}

Index Terms: Computer Fundamentals Course; classroom teaching expansion; teaching method

(C) 2012 Published by MECS Publisher. Selection and/or peer review under responsibility of the International Conference on E-Business System and Education Technology

\section{Introduction}

As the information technology which centers on computers has been widely applied to our daily life, the education of computer fundamentals has become an integral part of higher education system. The subject of "Computer Fundamentals" is one of the compulsory public courses for non-computer majors in universities, which aim to help students establish a complete knowledge structure in computer technology and to develop students' interdisciplinary research capabilities. In Henan Agricultural University, we set up the curriculum of "Computer Fundamentals", which weighs 3 credits, 60 hours (30 hours each for both theoretical and experimental lessons), for non-computer majors in the second semester.

Teaching quality has become the concern of all sectors including the government and the university since the implementation of expanding the enrollment of colleges in 1999 [1]. How to improve the course of "Computer Fundamentals" in the aim, contents, methods and exam's modes has become an important subject of teachers $[2,3]$ under the new circumstance. We manage to improve the teaching quality and students' computer skills by expanding classroom teaching of "Computer Fundamentals" in both time and space.

\section{Characteristics}

The contents of "Computer Fundamentals" include the basic knowledge of computers, the operating system, Microsoft Office applications, network basics, multimedia, information security, etc, and it is characterized as having much knowledge and flexible operability. Thus, it is difficult to cover all the aspects in detail in limited classroom teaching. In addition, computer science is a subject which updates constantly, and it has transcended

* Corresponding author.

E-mail address: shangjunping@sohu.com 
any previous discipline in the speed of updating in either software or hardware. Besides, teachers also need to update the classroom teaching of the subject constantly to keep pace with the development of computer technology. In this case, it will be very important for teachers to help the students master the contents of teaching, the knowledge and applications of computer skills by using effective classroom teaching expansion.

\section{Classroom Expansion Plan}

On the basis of the teaching content, we try to expand classroom teaching of the subject in the following aspects:

\section{A. Library Resources}

It being one of the three supports of teaching and scientific research in universities, the library enjoys rich literature and network information resources. It is the center of information resources of the school, and is also nicknamed as the second- class of the students. If the students can act on their own to read books in the library, they will surely gain knowledge beyond textbooks and will successfully change themselves from "passive accepter" to "active explorer". When the library resources are used effectively, it will definitely shed the limitations of classroom teaching, expand the teaching contents, and inspire students' eagerness for self-teaching to the greatest extent.

\section{B. Internet Resources}

Having been spread rapidly and widely, the Internet has become an important platform for information dissemination and transmission. Thus, it's no wonder that more and more news media, government agencies, enterprises and individuals are publishing information on the Internet. Moreover, the Internet has become "the fourth media" after the broadcast, newspaper and television, and is superior to all the other media in the amount, the speed and the variety of information.

The World Wide Web is virtually a library that is convenient and free of restrictions on time. Besides, it also contains useful resources such as the basic knowledge of computers, teaching materials, operation skills, product information and so on.

\section{Science and Technology Market}

The computer software and hardware updates so rapidly that knowledge on the textbook can not catch up with it. In the light of this statement, contents of teaching shouldn't be limited only to books.

As the distribution center of IT products and of scientific and technological information, the stage to show latest scientific and technological achievements and products and the trade center of high-tech products, the science and technology market has become the most ideal place for students to expand their classroom teaching. Specifically speaking, students can go there to conduct scientific researches, to perform exploitation of technology, to gain the latest information of high-tech products, etc. Schools such as Henan Agricultural University can organize students to carry out such researches and investigations in Henan Science and Technology Market, which is located in the north of Zhengzhou and is centered by a number of universities. And it is also known as "the hinterland Silicon Valley".

\section{Teaching Practices}

We ingeniously combine the contents of teaching with the expansion, which not only enriches the contents of teaching, cultivate students' interests in learning, but also inspire the eagerness within themselves and improve their ability of self-teaching. 


\section{A. Use the Library Resources}

Apart from introducing several classical reference books, we also guide students to read more books, and show them how to find relevant books of the subject quickly during the process of teaching. We introduce and demonstrate the school library booklist, CALIS Union-Catalog Database, Super Star digital library, CNKI and other literature resources to students in class, and this enables students to get to know the resources of the paper books, electronic books and other literature as well as the method to search for them when necessary.

When the students have mastered the contents of the textbooks, they are required to expand their horizons by reading more and accumulating more after gaining some knowledge about the resources of teaching reference. Besides, there's still one thing they can't miss, that is, to fulfill their book reports. Judging from their book reports, we can see that students have got a further understanding of basic computer knowledge. In addition, they have realized the importance of learning the course, and they can even define the concepts in their own words. More importantly, the sense of achievement can be achieved during the process of self-teaching.

\section{B. Application of the Internet Resources}

As the course nearly covers all the aspects of software and hardware, it will be too limited if the learners merely burry themselves in the textbooks and reference books.

Our country has started a project of establishing the essential courses to improve the quality of teaching and to promote the reformation of teaching among universities since the year 2003. According to the latest statistics, by June 2010 3,417 national essential courses and 6,978 provincial essential courses have been set up [4]. What's more, these courses are also shown on the Internet, and relevant syllabus, teaching plan, exercises, experimental direction, catalogue of bibliography are also provided free of charge. In this way, excellent teaching resources can be shared. The websites set up especially for the course have been one of the important resources for students to expand their horizons through self-teaching.

In the first class, the essential courses as well as the methods of how to retrieve by googling are advised to be introduced to students. Besides, teaching materials, such as E-teaching planning, PPT of teaching content, teaching cases, exercises, test papers and so on, can be browsed and downloaded to largely supplement are also necessary to be introduced to the students. Examples are preferred when it comes to search for certain types of teaching resources, for example, search the course slides by googling with the keywords[Computer Fundamentals filetype:ppt]. Other kinds of files by substituting [ppt] with the corresponding file extensions and further explanation will be made when introducing file types.

Besides, we'll come across all kinds of problems which are seldom mentioned in the textbook and often disturb the users during the process of using computers. For example, software/hardware troubles, the invasion of virus, etc. In the process of teaching, we try to guide the students to look for solutions to practical problems through the Internet. Various information can be found on the Internet including many Q\&As, which will be a great help when dealing with the problems. For example, if we forget the password, we can type in the words "what should be done when forget the logging password in windows XP operation system", and students can select a satisfying one from the many solutions provided on the web-pages. After a period of training, most of the students will get used to turning the Internet for help when facing problems, no matter whether they are about the subject or life. In this way, not only the practical problems can be solved but their ability to solve problems can also be improved.

\section{Investigation and Research in Science and Technology(Sci \&Tech) Market}

Along with having classes, reading books and writing book reports, students are asked, on the basis of preliminary acquisition of basic knowledge and relevant theories, to make investigation and research in sci \& tech market as a group of 3 5. Besides, they are also required to get out of the campus to broaden their horizons by learning the latest product information and maintenance experience. When investigating, students are advised to consult staff workers on information about hardware, including their functions and relevant parameters. In addition, it is also necessary to get the most suitable price for students, basic maintenance tips, etc. In order to 
make students share the results of their investigations, time should be assigned for them to communicate. As time is limited, representatives can be sent from groups. With what have been learned in science and technology market, they can communicate in their own words and from their own perspectives, which will definitely promote the efficiency. Before their investigation they simply had a skin-deep understanding of computer power supply and a vague image of the appearance and functions of the computer, but now they have got a better understanding and a much clearer image. Some students will look for further relevant product information on the Internet, specific parameters included, after having a rough knowledge about some product patterns. They show them to other students through the communication, which turns out to be a well practice and demonstration of class acquisition, class expansion and competence expansion. In the end, students also recommend the list that is usually acceptable, put forward some suggestions about how to assemble computers and talk about their feelings and advice on such investigations.

There do have problems in this activity. For example, some students may feel a bit disappointed about failing to have the staff workers introduce the appendices as they expected, and what they get is merely something about prices. After all, sci \& tech market is a market but not a school. Besides, misunderstandings of some definitions are inevitable, and students may even be misled by some staff workers because of their lacking of professional knowledge or professional morality. Installing the operating system are frequently mentioned among students, but when they ask the staff workers what it actually is, they are told that it is a system to save the file to a disk and to format. Meanwhile, some staff in a desktop computer store even claim that the laptop computer is unavailable to make drawings. To solve these problems, students should relearn the corresponding content in the textbook and redo the survey. Combining practice with relevant theories, one will surely develop himself into a computer expert some day in the future.

\section{Comparison of Teaching Effects}

Expansion activities have been conducted in the teaching of "Computer Fundamentals Course" for the students in the second semester of 2009-2010 as shown in Table 1. It lists up the comparison of scores between the 220 students in 8 classes with classroom teaching expansion and the 231 students in 8 classes without the expansion in the second semester of 2008-2009. It is seen that the application of the classroom teaching expansion could, to a certain degree, enhance students' computer skills, thus improving the teaching quality.

TABLE I. COMPARISON OF SCORES

\begin{tabular}{|c|c|c|c|c|c|c|c|}
\hline Semester & $\begin{array}{c}\text { Number of } \\
\text { Students }\end{array}$ & $\mathbf{9 0 - 1 0 0}$ & $\mathbf{8 0 - 8 9}$ & $\mathbf{7 0 - 7 9}$ & $\mathbf{6 0 - 6 9}$ & $<60$ & Average \\
\hline $2008-2009-2$ & 231 & 13 & 62 & 98 & 50 & 8 & 74.9 \\
\hline $2009-2010-2$ & 220 & 24 & 114 & 58 & 21 & 3 & 80.2 \\
\hline
\end{tabular}

\section{Conclusion}

During the process of teaching "Computer Fundamentals Course", we try to expand classroom teaching in both time and space. We also try to guide the students to use the library resources, the Internet resources, the science and technology market resources, etc. There is a great improvement in students' eagerness and capacity of learning, and their knowledge of the theories and skills of computers. From this we can see that students have really benefited a lot from these efforts. 


\section{References}

[1] Wang Yiqiu, "Some views on the current quality of undergraduate teaching," China University Teaching, vol. 3, pp. 4-14,2008(in Chinese).

[2] Fengyun Li, Ying Liu, Gao Fuxiang, "Research and Practice on the Teaching Reform of Computer Fundamentals Course," ifcsta, vol. 3, pp.35-37, 2009 International Forum on Computer ScienceTechnology and Applications, 2009.

[3] Xiu Li, Li Zheng, Fang Yang, "A General Education Curriculum on Computer Fundamentals--Needs Assessment and Design," The First ACM Summit on Computing Education in China, October 24-25, 2008, Beijing, China.

[4] Li Huijie, Ju Feng, Wang Hongyu, "National essential courses resource centre briefing [2010] No.6," http://www.tech.net.cn/page/N003/2010072200003.html,2010-07-22(in Chinese). 